\title{
BIOLOGICAL ACTIVITY OF FOUR MINOR NUTRIENT ELEMENTS AGAINST THE NEWLY HATCHED LARVAE OF THE PINK BOLLWORM, PECTIONOPHORA GOSSYIPELLA (SAUND.) LEPIDOPTERA : GELECHIIDAE
}

\author{
ELHAM F. M. ABDEL-RAHIM AND MEHASEN ABDEL -AZIZ
}

Plant Protection Res. Institute , ARC,Dokki, Giza

(Manuscript received 19 May 2008)

\begin{abstract}
The biological activity of four minor nutrient elements, Manganese(Mn) ,Copper ( $\mathrm{Cu}$ ) ,Iron (Fe) and zinc ( $\mathrm{Zn})$ was evaluated against the newly hatched larvae of the pink bollworm, Pectionophora gossyipella in a laboratory experiment. The newly hatched larvae were allowed to contact with a residual film at different concentrations of each mineral element until the pupation. The first element Manganese (Mn) was the most toxic one against the newly hatched larvae. The $L C_{50}$ value was $62.5 \mathrm{ppm}$, while the fourth element, zinc $(\mathrm{Zn})$ was the least toxic one. Its' $\mathrm{LC}_{50}$ value was $1200 \mathrm{ppm}$. The biological activities of the treated larvae were affected. The four tested elements had a similar effect in elongation the larval duration comparing with the control ,while Manganese only significantly increased in the pupal duration and pupal malformation percentages. Whereas, the two treatments, Manganese and Copper showed higher effect than other treatments on most of another biological parameters . Therefore, the pupation and the adult emergence percentages were depressed, and the pupil weight was decreased .Also, the adult fecundity, eggs fertility were inhibited, and the adult longevity was shortened .While the adult malformation percentages were more pronounced with the copper treatment. On the other side, the Iron treatment had the highest effect on the sex ratio of both adult males and females, it occurred males decreased and female increased, as compared to control, while the copper had an vis versa effect, it gave males increased and decreased in females as compared to the untreated ones.
\end{abstract}

\section{INTRODUCTION}

The pink bollworm, Pectinophora gossyipella is considered a notorious pest of the six most destructive insects in the world. It attack the flower, squares and bolls of cotton and cause serious damages to the principle cotton crop cost for farmers and consumers assessed by millions of dollars each year. In the developing countries, pesticides have played an extremely important role to maintain the high agricultural productivity. But the massive application of pesticides has created serious problems such as the build - up of pest resistance, the upsetting of natural balance ,and acute as well as, chronic hazards to man and animals(Franz,1974 and Mehesano, 1994). The use of resistant varieties is a trend for pest management. Plant and insects have a 
long time coexisted. plants possess defense mechanisms to maintain the plant integrity in their communities against preditors, competitors ,pathogens .Three mechanisms to account for plant's resistance to insect damage were proposed by Ayedh (1997).These are known as(i)Antixenosis describes the inability of a plant to serve as a host to insect herbivore. It has a particularity of modifying insect behavior once in contact with the plant host, without effect on metabolism of both plant and insect .There are several modes of resistance used by plant to deter insects. These modes were categorized as chemical and morphological plant defenses. There are two defense pathways but with a special emphasis on morphological plant surface characteristic associated to plant resistance. For examples of theses characteristics, plants present special epidermal characters (glandular trichomes, hairs... etc) and layers of surface waxes which prevent insects from feeding on them. Resistance to oviposition may come from plant characteristics that either fail to provide appropriate oviposition-inducing stimuli or to provide oviposition-inhibiting stimuli . The chemical inhibition of feeding can be through plant emition of allelochemicals such as repellents, deterrents or inhibitors. Each type of chemical defense engages the plant to different mechanisms to disturb insect behavior.(ii) Tolerance, is the ability of certain plants to withstand insect attack without appreciable loss in vigor or crop yield.(iii) Antibiosis, comprises the defensive mechanism of plants against their pests through adverse influence on growth, survival or reproduction of insects by means of chemicals or morphological factors. Phytochemicals play an important role in plant defences. A number of compounds have been showen to induce resistance in plants when applied to the foliage. Among the compounds demonstrated to have this effect are salicylic acid, potassium phosphate , a water solution of NPK fertilizer, certain plant extracts, and extracts of microbial metabolities. Also, among these chemicals are plant nutrients elements .There are 17 elements considered essential for plant growth. Three of them, carbon, hydrogen and oxygen are supplied by the air and water around us and are generally not thought of as fertilizers .Of the remaining 14 elements, nitrogen, phosphorus ,potassium, calcium, mangnasium and sulfure are considered macronutrients presented in most of plants at high concentrations e. $\mathrm{g}$ Brassica juncea ( Mark et al., 2000 ).While, Iron, manganese, zinc, copper, boron, molybdenum, chlorine and nickel recognized as micronutrients, often, were found at low concentrations in the plants. The most common approach is to add micronutrients to these plants as a foliar fertilizer essential for plant growth and as inducers for plant resistance against insect attack (Ruter, 2006), such as Micromax, generally contain iron, manganes, zinc, copper, boron and molybdenum .These elements serve many roles in plant metabolism and growth. Chlorine is an essential element for functioning 
of electron transport and water splitting in the photosynthetic process, whereas iron is important for numerous oxidation / reduction reactions. Boron is important for cell differentiation, division, and elongation, and copper is a key component of several enzyme complexes. Manganese and boron are essential for the proper germination and growth of pollen tubes. In Egypt more studies should be directed to test the mineral elements and their salts as relatively safe and cheapest pest control agents.

The aim of the present study was to evaluate the insecticidal and morphogentic activities of four minor nutrient elements against newly hatched of $P$. gossypiella larvae.

\section{MATERIALS AND METHODS}

\section{1-Insect rearing}

The newly hatched larvae of $P$. gossyipella used in this experiment were reared in the laboratory on semi-artifical diet inside glass vials $(2 \times 7.5 \mathrm{~cm}$.) according to Mohamed (1996) and incubated at 25Ć ,and 70_75\% R.H. until the pupation . The newly formed pupae were transferred to another glass vials, until the moths emergence. The newly emerged moths were sexed within glass chimneys provided with food and the deposited eggs were put into small jars until the egg hatching.

\section{2-Tested materials}

Four minor -nutrients elements were tested, Manganese(Mn) ,Copper ( $\mathrm{Cu})$, Iron ( $\mathrm{Fe}$ ) and zinc ( $\mathrm{Zn}$ ). They were obtained in a powder form of each element from Insecticides Department, Plant Protection Res. Institute, ARC, Giza, Egypt .

\section{3- Test procedures}

A series of different concentrations were prepared on the active ingredient basis (p.p.m) by diluting the weighed amounts of powder of each chemical element in water as solvent .About 6-7 concentrations ; 3000, 2000, 1000, 500, 250, 125 and $62.5 \mathrm{ppm}$ for each of the four tested elements were prepared. The exposure of newly hatched larvae for the elements depended upon the larval feeding on the film layer of each elements at different concentrations. The film layer was spread on the upper surface of the diet $(0.05 \mathrm{ml} / 3 \mathrm{gm})$ of each vile $(2 \times 7.5 \mathrm{~cm})$ and left to dry under air current until solvent evaporation. in each vial (Abdel -Rahim ,2002). Also a film layer of only water was spread over 3gm diet placed other glass vials and used as check with the same method. The newly hatched larvae were distributed above the treated and untreated diet and left until the pupation. Five replicates of fifty larvae for each concentration of each of the four tested elements were used .Also ,the observed malformations were recorded and photographed. 


\section{4-Statistical analysis}

The total percent of the larval mortality were recorded and corrected according to the check by using Abbott formula (Abbott ,1925). The data were then analyzed using probit analysis (Finney, 1952) and the LC $_{50}$ values were estimated for each of tested element. The different biological effects included larval and pupal duration, pupation and adults emergence percentage ,pupal weight, Adult fecundity, fertility, longevity, sex ratio were studied at the $\mathrm{LC}_{50}$ values, the data of the biology statically calculated through SPSS 10 for windows computer program to determined the F-value, P-value and L.S.D ( least significant difference at 0.05 or0.01freedom degrees).

\section{RESULTS AND DISCUSSION}

\section{1-Toxic effect}

Data presented in Table(1) showed that the four tested minor elements, Manganese(Mn) ,Copper(Cu) ,Iron(Fe) and zinc( $\mathrm{Zn})$ were effective against the newly hatched larvae of Pectinophora gossyipella (Saund). The first element( $\mathrm{Mn}$ ) was the most toxic one against the newly hatched larvae $\left(\mathrm{LC}_{50}=62.5 \mathrm{ppm}\right)$, while the fourth element ( $\mathrm{Zn})$ was the least toxic one $\left(\mathrm{LC}_{50}=1200 \mathrm{ppm}\right)$.

Table 1. Insecticidal activity of four minor nutrient elements at its LC50 values against the newly hatched larvae of Pectionophora gossyipella

\begin{tabular}{|c|c|c|c|c|}
\hline \multirow{2}{*}{ Compounds } & \multicolumn{4}{|c|}{ Newly hatched larvae } \\
\cline { 2 - 5 } & LC $_{50}$ values & \multirow{2}{*}{$\begin{array}{c}\text { Slope } \\
\text { function }\end{array}$} & \multicolumn{2}{|c|}{$95 \%$ Confidence limit } \\
\cline { 2 - 3 } \cline { 4 - 5 } & P.p.m. & 4.6 & 113 & Upper \\
\hline Manganese & 62.5 & 2.7 & 378 & 35 \\
\hline Copper & 210 & 3.3 & 700 & 357 \\
\hline Iron & 500 & 3 & 2640 & 546 \\
\hline Zinc & 1200 & & & \\
\hline
\end{tabular}

The effect of the micronutrient elements used was comparable to that caused by El- Sisi and Farrag (1989)they proved that copper carbonate was an effective as antifeedant against $4^{\text {th }}$ instar larvae of Spodoptera littoralis and produced a high mortality ,but none of the concentrations used caused apparent phytotoxicity. Also, Wada and Munakata (1968) demonstrated a feeding inhibition of larvae of $S$.littoralis that fed on castor oil leaves soaked in copper carbonate solution at different concentrations ranged $0.2-5 \%$ was occurred. Also Kabbe et al.(1976) reported that the use of trace nutrients ( such as salts of Iron , Managenese , Boron,Copper, Cabalt, Molybdenum and Zinc) mixed with certain chromenes compounds such as precocene 1 and precocene 11 are active compounds well tolerated by plants and means for combating arthropod pests, especially insects of order Lepidoptera ,Pectinophora gossyipella , Prodenia litura ,Spodoptera Spp., Earias insulana and Heliothis Spp. ,Jermy (1961)found a reduced feeding of Leptinotarsa decemlineata 
adult on potato leaf discs, giving almost total proection over 20h.at concentration of $6 \times 10-6 \mathrm{gm} / \mathrm{cm}$,but it appeared less effective against the larvae. This agree with those obtained by Verma et al.(1956) who showed a quick and accurate method for application of copper arsenic as insecticides e .g .Paris Green and Scheeles Green. Likewise, Friend (1945) showed insecticidal activity for Copper ,Manganese, Iron and Zinc . Brinley (1926) recorded that the feeding of Malacosoma americanum (F.)on bean seedlings is reduced if these are sprayed with copper stearate or copper resinate.

Table 2. Latent effect of $\mathrm{LC}_{50}$ values of four minor nutrient elements against newly hatched larvae of Pectionophora gossyipella .

\begin{tabular}{|c|c|c|c|c|c|c|c|}
\hline \multirow[t]{2}{*}{ Compounds } & \multirow{2}{*}{$\begin{array}{c}\text { Larval } \\
\text { duration } \\
\text { (days) } \pm \\
\text { S.D. }\end{array}$} & \multicolumn{2}{|c|}{$\begin{array}{c}\% \\
\text { Pupation } \\
\text { +S.D. } \\
\end{array}$} & \multirow{2}{*}{$\begin{array}{l}\text { Pupal } \\
\text { duration } \\
\text { (days) } \\
\text { 土S.D. }\end{array}$} & \multirow{2}{*}{$\begin{array}{c}\text { Pupal } \\
\text { weight } \\
(\mathrm{mg}) \\
\pm \text { S.E. }\end{array}$} & \multicolumn{2}{|c|}{$\begin{array}{c}\text { \% Adult } \\
\text { emergence } \\
\text { +S.D. }\end{array}$} \\
\hline & & Normal & Malfo. & & & Normal & Malfo. \\
\hline Manganese & $21.8 \pm 0.4 * *$ & $50 \pm 10 * *$ & $14.6 \pm 2 *$ & $13.3 \pm 0.8^{*}$ & $240 \pm 31 * *$ & $60.7 \pm 2 * *$ & $4.5 \pm 0.5 \mathrm{n} . \mathrm{s}$ \\
\hline Copper & $20.3 \pm 0.4 * *$ & $55 \pm 5^{* *}$ & $4.2 \pm 0.2 n . s$ & $10.4 \pm 3.3 \mathrm{n} . \mathrm{s}$ & $241 \pm 25 * *$ & $66.7 \pm 3 * *$ & $16.3 \pm 2 *$ \\
\hline Iron & $20.0 \pm 1.7^{* *}$ & $60 \pm 10 * *$ & $8.8 \pm 5.6 n . s$ & $10.0 \pm 1.8 \mathrm{n} . \mathrm{s}$ & $288 \pm 77 * *$ & $92.9 \pm 7 n . s$ & On.s \\
\hline Zinc & $19.8 \pm 1.9 * *$ & $65 \pm 10 * *$ & $6.1 \pm 0.2 \mathrm{n} . \mathrm{s}$ & $9.5 \pm 2.1 \mathrm{n} . \mathrm{s}$ & $305 \pm 62 * *$ & 96.8 n.s & $7.2 \pm 1 \mathrm{n} . \mathrm{s}$ \\
\hline Control & $11.8 \pm 1.3$ & 100 & 0 & $7 \pm 2.7$ & $488 \pm 82 * *$ & 100 & 0 \\
\hline F value & 103.64 & 256.5 & 76.245 & 16.304 & 28.9 & 802.7 & 343 \\
\hline$P$ value & 0.00584 & 0.00102 & 0.0593 & 0.027325 & 0.01166 & 0.0320 & 0.0029 \\
\hline $\begin{array}{l}\text { L.S.D at } \\
5 \% \text { level }\end{array}$ & 3.2 & 11.3 & 9.5 & 4.93 & 124.1 & 6.48 & 3.8 \\
\hline $1 \%$ level & 5.9 & 20.7 & 21.9 & 9.0 & 205.8 & 11.89 & 8.75 \\
\hline
\end{tabular}

\section{Latent effect}

\subsection{Larval and pupal periods}

Data in Table(2) demonstrated that the treatment of newly hatched larvae of $P$. gossypiella with the four tested elements at $\mathrm{LC}_{50}$ values caused, remarkable highly significant $(p<0.01)$ elongated the larval periods. The effect was observed with the four tested elements $\mathrm{Mn}, \mathrm{Cu}, \mathrm{Fe}$, and $\mathrm{Zn}$, respectively ranged from 21.8 to 19.8 days as compared to $11.8 \mathrm{~d}$. of the check.

On the other hand, the treatment of newly hatched larvae of $P$.gossypiella with only Manganese element at $L C_{50}$ values significantly $(p<0.05)$ increased the pupal period (Table2) to the average 13.3 days, as compared to that of control (7days). While, the other three elements $(\mathrm{Cu}, \mathrm{Fe}$ and $\mathrm{Zn})$ gave none significant increase in the pupal period which being $10.4,10.0$ and 9.5 days, respectively. 
These results are similar to those obtained by El-Sisi and Farrag (1989)they mentioned that the larval feeding of $4^{\text {th }}$ instar of $S$.littoralis on castor oil leaves sprayed with copper carbonate solution at different concentration (from 0.2 to $5 \% \mathrm{w} / \mathrm{v}$ ) retard the larval growth and prolonged the larval span.

\subsection{Pupation and Pupal weight}

Data in Table(2) demonstrated that the treatment of newly hatched larvae with the four tested elements at $L C_{50}$ values caused highly significant $(p<0.01)$ reduction in the pupation percent. The first and second elements ( $\mathrm{Mn}$ and $\mathrm{Cu}$ ) had the highest effect on the pupation, which reduced the pupation to 50 and $55 \%$, respectively, as compared to $100 \%$ of the check. While the third and fourth elements (Fe and $\mathrm{Zn}$ ) reduced the pupation to 60 and $65 \%$.

Likewise, the treatment of newly hatched larvae with the four tested elements at $\mathrm{LC}_{50}$ values gave highly significant $(\mathrm{p}<0.01)$ reduction in the weight of the resulted pupae. The first and second elements ( $\mathrm{Mn}$ and $\mathrm{Cu}$ ) were the most suppressive on the pupal weight where being 240 and $241 \mathrm{mg}$, respectively, as compared to $488 \mathrm{mg}$ of the check. While the third and fourth elements (Fe and $\mathrm{Zn}$ ) reduced the pupal weight to 288 and $305 \mathrm{mg}$, respectively.

These results are agreement with those obtained by El-Sisi and Farrag (1989) they found that the larval feeding of $4^{\text {th }}$ instar of $S$.littoralis on castor oil leaves sprayed with copper carbonate solution at different concentration ( from 0.2 to $5 \%$ $\mathrm{w} / \mathrm{v}$ ) prevented pupation or development to adults.

\subsection{Moths emergence}

Data in Table(2) indicated that the treatment of newly hatched larvae of $P$. gossypiella with the first and second elements ( $\mathrm{Mn}$ and $\mathrm{Cu}$ ) significantly $(\mathrm{p}<0.01)$ reduced the moths emergence to be average 60.7 and $66.7 \%$,respectively, as compared to $100 \%$ of the check. The third and fourth elements ( $F e$ and $\mathrm{Zn}$ ) induced none significant decrease in the moths emergence where averaged 92.9 and $96.8 \%$, respectively.

These are similar to that caused by a crude extract of the Melia azedarach against both P.gossypiella and E.insulana larvae which reduced the moths emergence of the two insects in respect to control (Rashad et al,1991) .

\subsection{Morphogenetic effects}

Data presented in Table(2) showed that the treatment of newly hatched larvae of P.gossypiella with Manganese at the $\mathrm{LC}_{50}$ values induced significant $(\mathrm{p}<0.05)$ increase in the pupal malformations to reach $14.6 \%$, as compared to $0 \%$ of the check. while the other three elements $\mathrm{Cu}$, Fe and $\mathrm{Zn}$ caused $4.2,8.8$ and $6.1 \%$, respectively.

With regard to adult malformations (Table2), it was found that the treatment of newly hatched larvae with the copper element $(\mathrm{Cu})$ induced significant $(p<0.05)$ increase of adult malformations to reach $16.3 \%$, as compared to $0 \%$ of control. While the other three elements $\mathrm{Mn}, \mathrm{Fe}$ and $\mathrm{Zn}$ induced in the adult abnormality $4.5,0$ and $7.2 \%$,respectively . 
Fig. 1-5 
These results are similar to that obtained by Mohamed (1996) who obtained underized larvae in both $P$. gossypiella and $E$.insulana treated with seed oil of Melia azedarach . Also, Solsoloy and Rejesus (1993) mentioned that petroleum ether and chloroform extracts of the crude oils from seed kernels or leaves of the physic nut, Jatropha curcas, induced larval-pupal intermediates and deformed adults of cotton bollworm, Heliothis armigera . Malformations of P.gossyipella pupae resulting from the treatment of newly hatched larvae in this work mostly appeared as larval_pupal intermediates (Fig.2) or pupal monstrosities(Fig.3) as compared to normal pupa (Fig.4), while the adult malformations often appeared as deformed wings of emerging adults(Fig.5) in relative to normal adult (Fig.6).

Table 3. Latent effect of $\mathrm{LC}_{50}$ values of four minor nutrient elements against the newly hatched larvae of Pectinophora gossyipella .

\begin{tabular}{|c|c|c|c|c|c|}
\hline \multirow[b]{2}{*}{ Compounds } & \multirow{2}{*}{$\begin{array}{c}\text { Fecundity } \\
\text { Mean+S.D. } \\
\text { (eggs/female) }\end{array}$} & \multirow{2}{*}{$\begin{array}{c}\text { Fertility } \\
\text { Mean } \pm \text { S.D } \\
\text { (eggs/female) }\end{array}$} & \multirow{2}{*}{$\begin{array}{l}\text { Longevity } \\
\text { Mean+S.D } \\
\text { (days) }\end{array}$} & \multicolumn{2}{|c|}{ Adult sex ratio } \\
\hline & & & & Male & Female \\
\hline Manganese & $5.5+4.1 * *$ & $3.5 \pm 2.9 * *$ & $7 \pm 1.2 * *$ & 1 & 1.5 \\
\hline Copper & $6.3 \pm 0.05^{* *}$ & $5.3 \pm 0.05 * *$ & $8.3 \pm 1.8 * *$ & 1 & 1 \\
\hline Iron & $9.6 \pm 1 * *$ & $5.9 \pm 0.7 * *$ & $8.8 \pm 1.3 *$ & 1 & 1.58 \\
\hline Zinc & $12.5 \pm 5.4 * *$ & $9.1 \pm 3.7 * *$ & $9.8 \pm 0.4 *$ & 1 & 1.28 \\
\hline Control & $125+16$ & $107 \underline{ \pm 11}$ & $16.8 \pm 2.2$ & \multirow{5}{*}{1} & \multirow{5}{*}{1.14} \\
\hline$F$ value & 265.15 & 210.3 & 45.3 & & \\
\hline$P$ value & 0.004162 & 0.005185 & 0.01233 & & \\
\hline $\begin{array}{l}\text { L.S.D at } \\
5 \% \text { level }\end{array}$ & 32 & 31.0 & 4.5 & & \\
\hline $1 \%$ level & 73.8 & 71.6 & 8.3 & & \\
\hline
\end{tabular}

\subsection{Adult fecundity and fertility}

Treatment of $P$. gossypiella newly hatched larvae with the four tested elements (Table 3 ) lead to highly significant $(p<0.01)$ reduction in the fecundity of adult females. The first and second elements ( $\mathrm{Mn}$ and $\mathrm{Cu}$ ) had the highest effect on the fecundity, it averaged 5.5 and $6.3 \mathrm{egg} / \mathrm{f}$, respectively , as compared to $125 \mathrm{eggs} / \mathrm{f}$ of the check. Whereas the third and fourth elements (Fe and $\mathrm{Zn}$ ) reduced the fecundity to be 9.6 and 12.5 eggs/f, respectively.

Likewise, the larval feeding of $P$. gossyipella on the four tested elements at the $\mathrm{LC}_{50}$ values caused highly significant $(\mathrm{p}<0.01)$ reduction in the eggs fertility (Table 3).The first and second elements ( $\mathrm{Mn}$ and $\mathrm{Cu}$ ) had the most potent effect on eggs 
fertility, where the two elements inhibited eggs fertility to be average 3.5 and 5.3 eggs/f, respectively, as compared to $107 \mathrm{eggs} / \mathrm{f}$ of the check. Whereas, the third and fourth elements (Fe and $\mathrm{Zn}$ ) decreased the eggs fertility to 5.9 and 9.1 eggs/f , respectively.

The same results was obtained by Hashem et al.(1994) who demonstrated a reduction in both fecundity and fertility as a result of abnormalities in the ovaries of $S$ .littoralis adults fed as $4^{\text {th }}$ instar larvae on artifical diet mixed with $2 \%$ of fruit extract of M. azedarach for $72 \mathrm{~h}$. Likewise, Jermy (1961) recorded an oviposition inhibition of Leptinotarsa decemlineata adults that fed on potato leaf discs treated with copper sulphate due to the adult females are deprived of food ( because the copper acts antifeedant factor).

\subsection{Adult longevity}

The results in Table (3) indicate that the treatment of newly hatched larvae of $P$ .gossyipella with the first and second elements $(\mathrm{Mn}$ and $\mathrm{Cu}$ ) caused a highly significant $(p<0.01)$ decrease in the longevity of emerged adults to average 7 and 8.3 days, respectively, as compared to 16.8 days of the check. Whereas, the third and fourth element(Fe and $\mathrm{Zn})$ significantly $(\mathrm{p}<0.05)$ decreased the adult longevity to average 8.8 and 9.8 days., respectively.

\subsection{Adults sex ratio}

Data in Table(3)showed that the treatment of newly hatched larvae of $P$. gossyipella with the four tested elements at $\mathrm{LC}_{50}$ values shifted the sex ratio, it decreased the males and increased the females percent, as compared with the check . The effect was more pronounced with the third element ( $\mathrm{Fe})$, where the adult males and females ratio was 1:1.58 for the two sexes, respectively, as compared to $1: 1.14$ of adult males and females ratio, respectively of control. While the treatment of newly hatched larvae of $P$.gossyipella with the first, second and fourth elements ( $\mathrm{Mn}, \mathrm{Cu}$ and $\mathrm{Zn}$ ) gave a relatively same males and females ratio of the control which being $1: 1.2,1: 1$ and1:1.28 for both sex ,respectively .

\section{CONCLUSION}

The results of the present work demonstrated that the four minor nutrient elements were effective against the survival and biology of $P$. gossyipella, this was more observation with Managenese and copper treatments and also, most of the tested biological activities of the insect were more affected with the two treatments ( $\mathrm{Mn}$ and $\mathrm{Cu}$ ), but some of biological activities were more affected with Iron treatments . Thus, the elements solution may spray at the obtained $\mathrm{LC}_{50}$ values as foliar fertilizer 
(Ruter,2006) or over the flower bud and bolls to improve the plant growth because of it acts as plant inducers and avoid the pest infestation due to its toxic action on the pest, thus these elements may give safe self - protection of the plant and use as replacement means for the synthetic insecticides that caused serious effects on the environment.

\section{REFERENCES}

1. Abbott, W. S. 1925. A method of computing the effectiveness of an insecticide .J . Econ.Entomol., 18: 265-267.

2. Abdel-Rahim. 2002. Effect of some botanical extracts and growth regulators on Agrotis ipsilon and Earias insulana .Ph.D.Thesis, faculty of Science, Cairo -Univ

3. Ayedh, A. 1997.The Effect of Plant Resistance on Insect Behavior .hayala @ lamar.colostate.edu

4. Brinley, F. J. 1926. Insecticidal value of certain war chemicals as tested on the ten caterpillar. J. Agric.Res., 33,177-182..

5. El_Sisi, A.G. and R. M. Farrag. 1989. Formulation and biological effects of copper carbonate against The Egyptian cotton leafworm Spodoptera littoralis (Boisd.).Agric. Res. Review, 67(1), 29-35

6. Finney, D.J.1952. Probit analysis, $3^{\text {rd }}$. edition , Cambridge University Press,pp.333.

7. Friend, A. H. 1945. Experiments on the control of bean seed weevil. J. Aust. Inst . Agric.Sci., 11(3):139-141

8. Franz, J. M. 1974. Testing of side-effect of pesticides on beneficial arthropods in laboratory. Z. Pflkrankh.pflschutz, 81:141-174.

9. Hashem, H.O., A.M. Kheirallah, M.H. Swidan and W.E. Osman. 1994. Effect of alcoholic fruit extract of Meliaazedarach L. on the ovaries, fecundity and fertility of cotton leafworm moths Spodoptera littoralis (Boisd.).Alexandria J. of Agriculturalresearch, 39:1,211-227.

10. Jermy. 1961. The rejective effect of some inorganic salts on the Colorado beetle(Leptinotarsa decemlineata, Say) adults and larvae-Noenyved .Kut .Intez .Evk.8,121-130(In Hungarian).

11. Kabbe, Hans-Joachim, Roessler and peter. 1976. Combating arthropods with 2substituted - chroman-4-ones .Chem.Eng.News,No16 page 19.

12. Mark P. E. , J. B. Michael, W. H. Jianwei and D. G. Christopher. 2000. Plants as a natural source of concentrated mineral nutritional supplements. J. Food Chemistry 71, 181-188.

13. Mehesano, A. A. 1994. Ecology and the general health ,El-Shorouk establishment for republishing,No,2. 
14. Mohamed, M. A. 1996. Some biological and physiological studies on the effect of some I.G.Rs and plant extracts Pectionophora gossyipella and Earias insulana Ph.D. Thesis Plant Protection Department, Faculty of Agriculty .Al-Azhar Univ.

15. Rashad, A.M., S. H. Taher, S. M. Naguib and N. M. Abdel-Salam. 1991. Effect of Melia azedarach extraction Earias insulana and Pectionophora gossyipella. Egypt .J.Cont., 1:117_120.

16. Ruter, J. M. 2006. Micronutrients for soilless substrates. Georgia University., Horticulture Department.

17. Solsoloy, A. D. and B. M. Rejesus. 1993. Juvenile hormone effect of the insecticidal principle from psychic nut, Jatropha curcas Linn. On cotton bollworm, Helicoverpa armigera (Hubn). Philippines univ. Inc. college, Laguna (Philippines), p.34.

18. Wada, K. and K. Munakata. 1968. Naturally occurring insect control chemicals in the leaves of Cocculus trilobus, J. Agric. Food Chem.,16:471-474.

19. Verma, M. R., V. M. Bhuchar and Ramjdass. 1955. Amodified method for the assay of arsenical insecticides part 1-paris green: J. Fresenius J. of Analytical chemistry vol.149,November(1956). 


\title{
دراسة النشاط البيولوجى لأربعة عناصر صغرى ضد يرقات الفقس العديث لاودة اللوز (القرنقلية (حرشفية الأجنحة)
}

\author{
الهام فاروق محمود عبد الرحيم ، محاسن عبد العزيز أحمد \\ معهُ بحوث وقاية النباتات - مركز البحوث النراعية - الدقى - الجيزة .
}

اجريت هذه الدراسات بغرض تقيم التاثير السمى لاربعة عناصر غذائية صغرى وهى المنجنيز،

النحاس، الحديد، الزنك اختبرت معطيا ضد برقات الفقس الحديث لدودة اللوز القرنفلية.تركت برقات الفقس الحديث فى تلامس مع فيلم متنقيات لهذه العناصر يعلو الوجبة الصناعية المستخدمة كغذاء

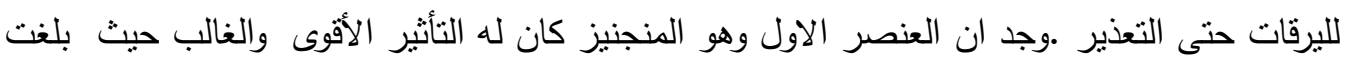

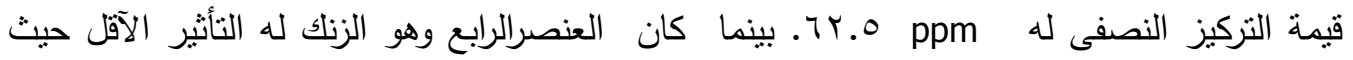

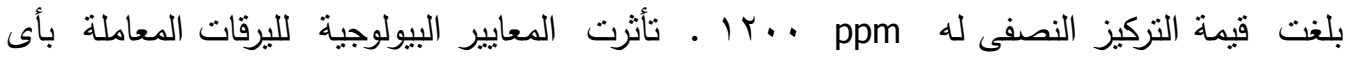

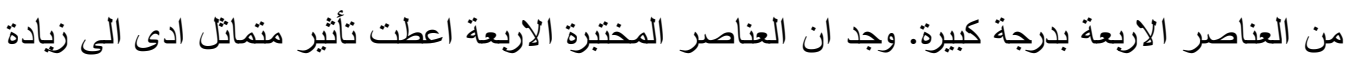

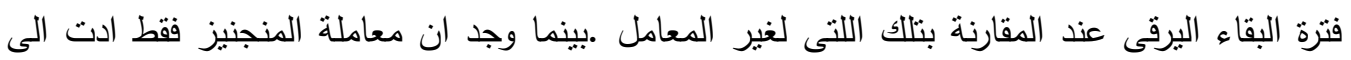

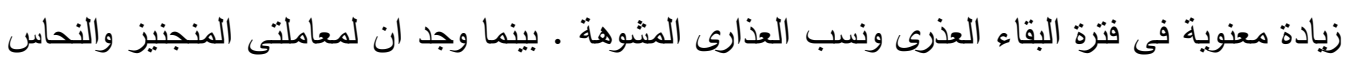

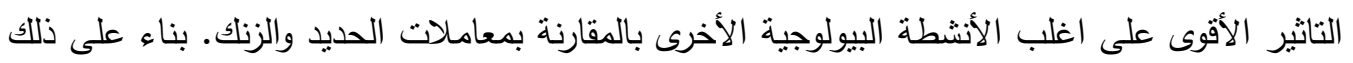

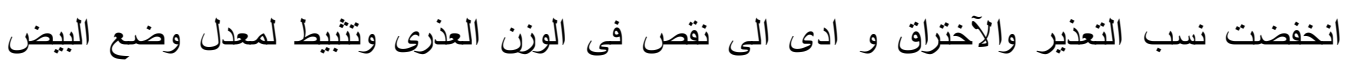

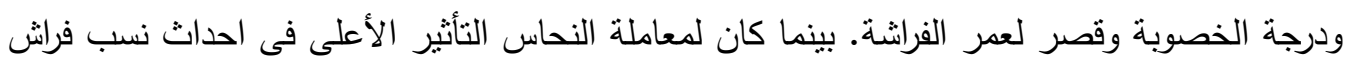

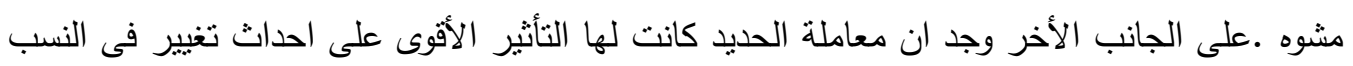

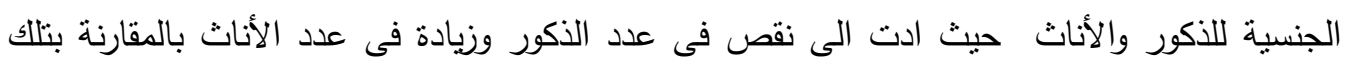

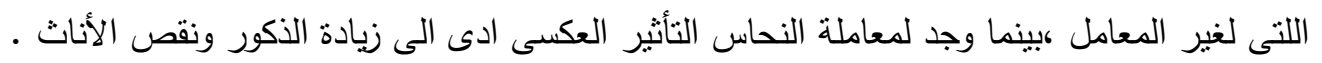

